\title{
The concurrent use of hyponatremia-inducing drugs in older patients, a case report
}

Hiponatremiye neden olan ilaçların yaşı hastalarda eşzamanlı kullanımı: Bir vaka sunumu

Fatma Ece Kocaoğlu(D) Tahir Belice (D) İsmail Demir (D) Arif Yüksel(D)

Department of Internal Medicine, University of Health Sciences, Bozyaka Training and Research

Hospital, Izmir, Turkey

\begin{abstract}
While the value of preventive healthcare services comes up repeatedly, the healthcare professionals are now trying to find solutions for the expanding geriatric population's problems before they occur. The risk of drug-drug interactions may get preventively reduced in older patients with the selection of co-medications that are less likely to interact. The choice of drugs for older patients is crucial when commencing with potential incriminated agents together, such as, serotonin and norepinephrine reuptake inhibitors, selective serotonin reuptake inhibitors, diuretics, proton pump inhibitors, nonsteroidal anti-inflammatory drugs, etc., which could interact with each other and cause hyponatremia in a short period of time. In this paper, a rare case of an older patient with venlafaxineinduced hyponatremia has been presented.
\end{abstract}

Keywords: Aged, venlafaxine hydrochloride, hyponatremia, diuretics.

\section{öz}

Koruyucu sağlık hizmetlerinin önemi tekrar tekrar gündeme gelirken, sağlık profesyonelleri artık, artan geriatrik nüfusun sorunlarını, henüz ortaya çıkmadan, irdeleyerek çözümler aramaktadır. Geriatrik hastalarda ilaç-ilaç etkileşimi riski, etkileşme olasılığı daha düşük olan ilaç grupları seçilerek kısmen de olsa önlenebilmektedir. Geriatrik hastalarda ilaç seçimi, kısa sürede hiponatremiye neden olabilecek serotonin-norepinefrin geri alım inhibitörleri, seçici serotonin geri alım inhibitörleri, diüretikler, proton pompa inhibitörleri ve non-steroidal anti-inflamatuvar ilaçlar gibi potansiyel medikasyonların kullanımında önemli olabilmektedir. Bu olgu sunumunda venlafaksin kullanımı sonrası hiponatremi gelişen bir geriatrik hasta sunulmuştur.

Anahtar Sözcükler: Yaşlı, venlafaksin hidroklorür, hiponatremi, diüretikler.

\section{INTRODUCTION}

Nowadays, venlafaxine is a serotonergic and noradrenergic antidepressant widely used as an alternative to selective serotonin reuptake inhibitors (SSRIs). Since we know that venlafaxine and SSRI antidepressants' efficacy are similar and limited especially in older adults with chronic diseases, the physicians have to evaluate the patients in detail before commencing them (1). Not only co-medication and polytherapy, but also other factors such as poor physiological conditions in older people, genetic background (metabolizers) and chronic diseases, can play a role in the drug-drug interaction (1).

\footnotetext{
Corresponding author: Arif Yüksel

Department of Internal Medicine, University of Health

Sciences, Bozyaka Training and Research Hospital, Izmir

Turkey

E-mail: ayüksel68@gmail.com
} 
Chronically low serum sodium $(\mathrm{Na})$ concentrations tend to be the least symptomatic. Older people are also at the highest risk of severe side effects such as central pontine myelinolysis if the $\mathrm{Na}$ concentration is corrected too rapidly. Still, hyponatremia tends to be asymptomatic in the setting of chronically low serum $\mathrm{Na}$ concentrations. As we know, the most common causes of hyponatremia are as follows: The syndrome of inappropriate antidiuresis, drugs, polydipsia, adrenal insufficiency, hypervolemia, and other diseases (e.g., heart failure, liver cirrhosis). The most important drugs associated with asymptomatic or symptomatic hyponatremia are diuretics, antidepressants, and antiepileptics (2). Antidepressant-induced hyponatremia, which is mostly related to the use of psychotropic agents, including serotonin and norepinephrine reuptake inhibitors (SNRIs) and SSRIs, can cause significant morbidity and mortality in older patients. The "tea and toast" phenomenon is also known as another factor that could be a potential contributor to hyponatremia in older patients with a diet deficient in protein and $\mathrm{Na}$. The risk of drug-drug interactions could be preventively reduced in older patients with the selection of co-medications that are less likely to interact with each other. In this case, we report a rare cause of hyponatremia in an older patient and criticize whether hyponatremia's main reason could be venlafaxine or the combined effect of venlafaxine and hydrochlorothiazide. The authors certify that they have obtained all appropriate patient consent forms.

\section{CASE PRESENTATION}

A female patient aged 88 years was admitted to our hospital's physical therapy service due to her gonarthrosis. We learned that the patient had taken valsartan and hydrochlorothiazide as antihypertensive drugs for about ten years, and also the patient had been on a low-sodium diet for high blood pressure. Her medical history did not reveal any other specific feature. On physical examination, the heart was in sinus rhythm, and there was no pretibial edema. Her respiratory system examination was normal. She was not dyspneic and tachycardic. The patient had no other complaints including fever, dysuria, vomiting, thirst or diarrhea, etc. No pathologies, such as kidney failure, heart failure, head injury history, or malabsorption were previously known and no disruptive fluid and electrolyte balance were encountered.
The patient was given on acetaminophen $500 \mathrm{mg}$ tablet once a day and ketoprofen gel twice a day until she was discharged after ten days of hospitalization. The patient was consulted with psychiatry on the second day of her hospitalization for unhappiness and sudden uncontrollable crying complaints lasting for a few months. After had been diagnosed with moderate depression disorder, a venlafaxine tablet was started for her treatment. The Na level was 137 $\mathrm{mg} / \mathrm{dl}$ on the first day of admission. On the second day of the venlafaxine treatment, the patient was consulted to us for hyponatremia since the patient's $\mathrm{Na}$ value was reduced to 124 $\mathrm{mg} / \mathrm{dl}$ and the serum osmolarity was 288 $\mathrm{mOsm} / \mathrm{L}$. After detailed medical history taking, the patient's treatment was rearranged, considering the fact that hyponatremia developed primarily due to drug interaction or initiation of venlafaxine alone. Lercadipin tablet was started once daily instead of valsartan and hydrochlorothiazide for hypertension, but the psychiatrist advised not to start any other antidepressant for a while instead of venlafaxine. Since the patient had symptoms such as headache and weakness, hypertonic fluid was started for hyponatremia, and $\mathrm{Na}$ value reached $135 \mathrm{mg} / \mathrm{dl}$ at the end of the third day. The patient was discharged after being informed that she needs to come to the outpatient clinic for $\mathrm{Na}$ control.

\section{DISCUSSION}

Hyponatremia is common in older adults with the incidence varying between $11 \%$ and $18 \%$, and its underlying reason can be a psychoactive drug. So after starting such therapies in older patients, electrolytes should be measured within 2-5 days. We have just found a few studies and a handful of case reports presenting data on hyponatremia with venlafaxine in the medical bibliography. Most of them are limited to older patients. In a cohort study, $89.0 \%$ of 54.038 participants aged 65 and over received at least one antidepressant $(54.7 \%$ SSRIs, $31.6 \%$ tricyclic antidepressants, $0.2 \%$ monoamine oxidase inhibitors, $13.5 \%$ other antidepressants). During follow up between 1996 and 2007, venlafaxine was found to be associated with higher adjusted hazard ratios for stroke / transient ischemic attack, fracture, and epilepsy / seizures than the other drugs (3). In a review, both SSRIs and venlafaxine, especially when added on the patient's risk factors such as 
older age $(\mathrm{OR}=6.3)$ and concomitant use of diuretics (thiazide) $(O R=11.2$ - 13.5), was found to have a potentially dangerous side effect such as hyponatremia (4). Because the serum osmolarity was in the normal range and there was no history of head trauma, thyroid diseases, cancer, etc., and any other causes of dilutional hyponatremia such as heart failure, kidney failure, or liver cirrhosis, we treated our case as hyponatremia due to usage of potentially inappropriate medication that could cause electrolyte disturbance in an older patient.

Furthermore, the cause of hyponatremia might be a result of the synergistic effect potentiated by venlafaxine and hydrochlorothiazide combined together. The gradually lowering of $\mathrm{Na}$ and fast recovery from hyponatremia after the withdrawal of drugs made us focus on the interaction between concurrent use of hyponatremic drugs. The low $\mathrm{Na}$ concentrations of most patients who are on the medication of SNRIs / SSRIs, return to normal range within days or weeks after withdrawal. We had the same results in our case. If hyponatremia worsens the problem can be managed with modest fluid restriction, subjecting the patient to close continued clinical observation and biochemical monitoring instead of discontinuing drug treatment. As the population age, the importance of choosing appropriate drugs for older patients has emerged. For example, whether some of the drugs such as SNRIs, SSRIs, diuretics, proton pump inhibitors and nonsteroidal anti-inflammatory drugs have a potential risk or not for hyponatremia, should be taken into consideration by a physician when prescribing them for older patients (5). Moreover, the Dutch Pharmacogenetics Working Group of the Royal Dutch Association for the Advancement of Pharmacy recommends venlafaxine dosing based on CYP2D6 genotype, which is not possible for many countries routinely at the moment.

\section{CONCLUSION}

All in all, most older adults with chronic diseases are susceptible to electrolyte abnormalities, including hyponatremia. The combined use of medications potentially causing hyponatremia such as diuretics and some psychoactive drugs could be proactively avoided by physicians, especially for those patients that are at risk. Physicians should bear in mind that older patients have a higher propensity to develop hyponatremia after starting venlafaxine therapy, especially with those on diuretics.

Conflicts of interest: There are no conflicts of interest.

\section{References}

1. Venlafaxine: more dangerous than most "selective" serotonergic antidepressants. Prescrire Int $2016 ; 25$ (170): 96-9.

2. Liamis G, Megapanou E, Elisaf M, Milionis H. Hyponatremia-Inducing Drugs. Front Horm Res 2019; 52: $167-77$.

3. Coupland C, Dhiman P, Morriss R, Arthur A, Barton G, Hippisley-Cox J. Antidepressant use and risk of adverse outcomes in older people: population-based cohort study. BMJ 2011; 2 (343): d4551.

4. De Picker L, Van Den Eede F, Dumont G, Moorkens G, Sabbe BG. Antidepressants and the risk of hyponatremia: a class-by-class review of literature. Psychosomatics 2014; 55 (6): 536-47.

5. Filippatos TD, Makri A, Elisaf MS. Hyponatremia in the elderly: challenges and solutions. Clin Interv Aging 2017; 14 (12): 1957-65. 